\title{
Wickerhamomyces queroliae sp. nov. and Candida jalapaonensis sp. nov., two yeast species isolated from Cerrado ecosystem in North Brazil
}

Correspondence

Carlos A. Rosa

carlrosa@icb.ufmg.br

\author{
Carlos A. Rosa, ${ }^{1}$ Paula B. Morais, ${ }^{2}$ Marc-André Lachance, ${ }^{3}$ \\ Renata O. Santos, ${ }^{1}$ Weilan G. P. Melo, ${ }^{2}$ Rodney H. O. Viana, ${ }^{2}$ \\ Marcos A. L. Bragança ${ }^{2}$ and Raphael S. Pimenta ${ }^{2}$ \\ ${ }^{1}$ Departamento de Microbiologia, ICB, C.P. 486, Universidade Federal de Minas Gerais, \\ Belo Horizonte, MG 31270-901, Brazil \\ ²Laboratório de Microbiologia Ambiental e Biologia, Campus Universitário de Palmas, Fundação \\ Universidade Federal do Tocantins, Palmas, Tocantins 77020-210, Brazil
}

${ }^{3}$ Department of Biology, University of Western Ontario, London, ON N6A 5B7, Canada
Two novel yeast species, Wickerhamomyces queroliae sp. nov. and Candida jalapaonensis sp. nov., were isolated, respectively, from larvae of Anastrepha mucronata (Diptera: Tephritidae) collected from ripe fruit of Peritassa campestris ('Bacupari', Hippocrateaceae) and from flowers of Centropogon cornutus (Campanulaceae) in the Cerrado ecosystem of the state of Tocantins, Brazil. Analysis of the D1/D2 large-subunit rRNA gene sequences placed W. queroliae in the Wickerhamomyces clade near Wickerhamomyces ciferri and Candida silvicultrix. Candida jalapaonensis belongs to the Wickerhamiella clade and is related to Candida drosophilae. The type strain of Wickerhamomyces queroliae is UFMG-05-T200.1 $1^{\top}$ (=CBS $10936^{\top}=\mathrm{NRRL} Y-$ $\left.48478^{\top}\right)$ and the type strain of Candida jalapaonensis is UFMG-03-T210 ${ }^{\top}(=\mathrm{CBS}$ $10935^{\top}=$ NRRL $Y-48477^{\top}$ ).
The Brazilian Cerrado is considered to be a biodiversity hotspot (Myers et al., 2000). This ecosystem is characterized by the occurrence of a large number of endemic species of plants and animals. However, extensive studies of the microbial diversity from this ecosystem are scarce. Only four novel yeast species, Ogataea falcaomoraisii, Candida azymoides, Metschnikowia cerradonensis and Moniliella fonsecae, have been described from natural sources in the Cerrado ecosystem (Morais et al. 2004; Rosa et al., 2006, 2007, 2008). During a survey of yeasts associated with various substrates from the Cerrado ecosystem in the state of Tocantins, northern Brazil, several strains were isolated. Two isolates were obtained from larvae of Anastrepha mucronata (Diptera: Tephritidae) collected from ripe fruit of Peritassa campestris ('Bacupari', Hippocrateaceae). Other isolates were from flowers of Centropogon cornutus (Campanulaceae). Analysis of the sequences of the D1/D2 domains of the large-subunit rDNA showed that these strains represent phylogenetically distinct species, the first isolate being related to the Wickerhamomyces clade and the second to the Wickerhamiella clade. In this paper, we describe two novel species, for which the names

The GenBank/EMBL/DDBJ accession numbers for the sequences reported in this paper are EU580139 and EU580140.
Wickerhamomyces queroliae sp. nov. and Candida jalapaonensis sp. nov. are proposed.

Details of the strains considered in this study are given in Table 1. Larvae of A. mucronata (Tephritidae) were collected directly from decaying fruit of $P$. campestris in an Ipuca forest fragment from the Cerrado ecosystem, in October 2005 (Rosa et al. 2006). The larvae were collected with sterile forceps, surface-sterilized by immersion in $70 \%$ ethanol for $1 \mathrm{~min}$, and placed on plates of YM agar $(0.3 \%$ yeast extract, $0.3 \%$ malt extract, $0.5 \%$ peptone, $1.0 \%$ glucose, $2 \%$ agar, and $100 \mathrm{mg}$ chloramphenicol $\mathrm{l}^{-1}$ ). Flowers of Centropogon cornutus (Campanulaceae) were collected near a road at a distance of approximately $100 \mathrm{~m}$ of a waterfall (Cachoeira da Velha) in the State Park of Jalapão, state of Tocantins, in September 2003. The nectary region of the flowers was scraped gently with a sterile loop and streak-inoculated onto YM agar. The plates were incubated at room temperature $\left(25 \pm 3{ }^{\circ} \mathrm{C}\right)$ for 3-8 days. Each different yeast morphotype was purified and maintained on YM slants or in liquid nitrogen storage for later identification. The yeasts were characterized using standard methods (Yarrow, 1998). Identities were verified using the keys of Kurtzman \& Fell (1998). Sporulation was investigated using malt extract, glucose-yeast extract, yeast carbon base plus $0.01 \%$ ammonium sulfate, V8, cornmeal, 
Table 1. List of isolates of Wickerhamomyces queroliae and Candida jalapaonensis

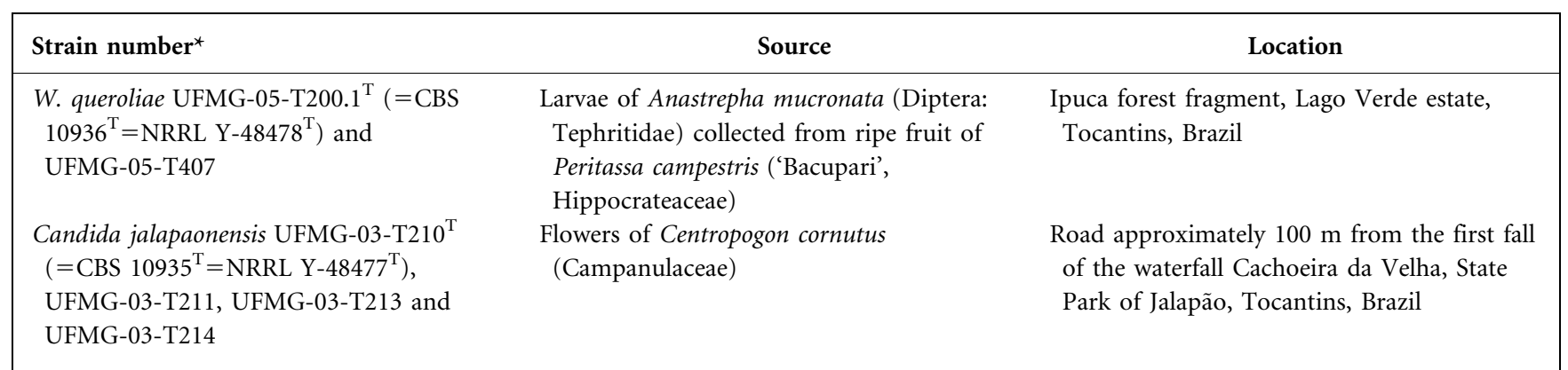

*UFMG, Universidade Federal de Minas Gerais, Brazil; CBS, Centraalbureau voor Schimmelcultures, The Netherlands; NRRL, ARS Culture Collection, Peoria, IL, USA.

Gorodkowa and YM agars at $22{ }^{\circ} \mathrm{C}$ for 3 weeks. The heat treatment technique described by Wickerham \& Burton (1954) was used to determine whether $W$. queroliae sp. nov. was homothallic or heterothallic.

The D1/D2 variable domains of the large-subunit rDNA were amplified by PCR directly from whole cells, as described previously (Lachance et al., 1999). The amplified DNA was concentrated and cleaned on QIAquick PCR columns (Qiagen) and sequenced using an ABI sequencer at the John P. Robarts Research Institute (London, Ontario, Canada). The sequence was edited with the program DNAMAN, version 6 (Lynnon BioSoft). Sequences for other yeasts were retrieved from GenBank. CLUSTAL W software (Thompson et al., 1994) was used to align the sequences and a neighbour-joining tree was constructed based on 1000 bootstrap iterations.

\section{Classification, ecology and species delineation}

The genus Wickerhamomyces was proposed by Kurtzman et al. (2008) to accommodate 17 phylogenetically related species formerly assigned to Pichia, Williopsis and Hansenula. The genus was phylogenetically circumscribed from an analysis of large-subunit and small-subnit rRNA and EF- $1 \alpha$ gene sequences and is a sister genus to Lindera, another collection of species formerly assigned to the three aforementioned taxa. The type species of Wickerhamomyces is Wickerhamomyces canadensis. Based on the sequences of the D1/D2 region of the large-subunit rRNA gene, $W$. queroliae sp. nov. occupied a basal position with respect to several species that included $W$. ciferrii and Candida silvicultrix (Fig. 1). In terms of sequence divergence, $W$. queroliae sp. nov. differed by 21 substitutions and 31 gaps from Candida silvicultrix, and by 23 substitutions and 30 gaps from $W$. ciferrii in the D1/D2 region of the largesubunit rRNA gene. The isolates of this novel yeast species were obtained from larvae of A. mucronata, suggesting that the yeast is associated with this insect. A. mucronata is a frugivorous fly, and other species of this genus are considered pests for many different kinds of fruits (CruzLópez et al. 2006). However, there is no record of significant economic damage being caused by this fly species. A. mucronata was collected from fruit of $P$. campestris and also probably attacks other fruits of the Cerrado ecosystem. The habitat of $W$. queroliae sp. nov. could probably be this fly and fruit of the Cerrado ecosystem. Two to four hat-shaped ascospores were produced from single colonies of $W$. queroliae sp. nov. when grown on dilute $(1: 19)$ V8 agar. After heat treatment, according to Wickerham \& Burton (1954), 15 colonies of $W$. queroliae were transferred individually to plates of dilute V8 agar. The plates were incubated for 14 days at $25{ }^{\circ} \mathrm{C}$, and ascospores were produced, showing that $W$. queroliae sp. nov. is homothallic. W. queroliae sp. nov. can be distinguished from $W$. anomalus and $W$. ciferrii based on growth on cellobiose, raffinose and

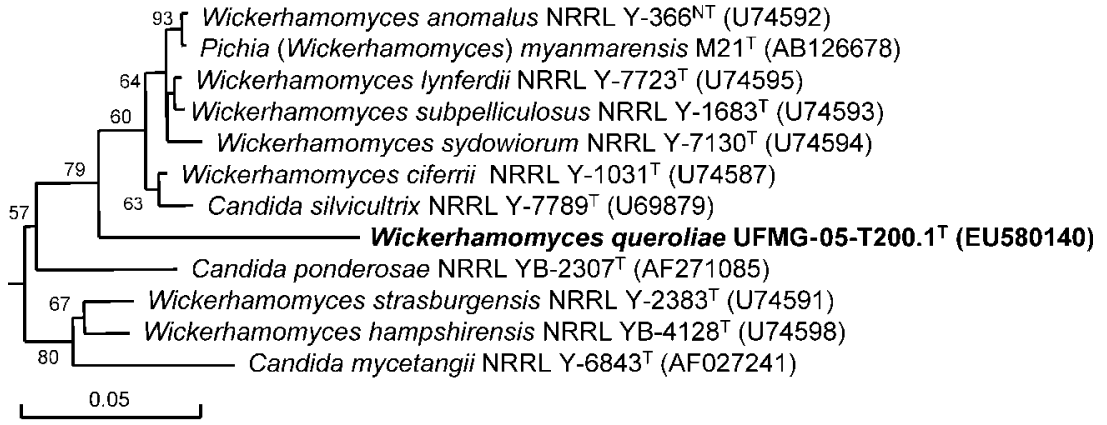

Fig. 1. Neighbour-joining tree based on largesubunit rRNA genes showing the placement of Wickerhamomyces queroliae among related species in the Wickerhamomyces clade. Bootstrap values greater than $50 \%$ are shown. Bar, 5 substitutions per 100 nucleotides. 
melezitose, which is positive for $W$. anomalus and $W$. ciferrii and negative for the novel species.

Candida jalapaonensis sp. nov. belongs to the Wickerhamiella clade and is a sister species to Candida drosophilae. The two species differed in 14 bases and two gaps in the D1/D2 region of the large-subunit rDNA (Fig. 2). Four strains of the novel species were isolated from flowers of Centropogon cornutus in the State Park of Jalapão, state of Tocantins, Brazil. Yeast species from the Wickerhamiella clade are frequently associated with flowers and floricolous insects (Lachance et al., 1998, 2000). Flowers of Centropogon cornutus are frequently visited by insects and also by hummingbirds, and these probably serve as vectors of this yeast in the Cerrado ecosystem. Isolates of Candida jalapaonensis sp. nov. were examined individually or as a mixture of two strains on cornmeal, V8, dilute V8, $5 \%$ malt extract, yeast carbon base supplemented with $0.01 \%$ ammonium sulphate and Gorodkowa agars, but no asci or signs of conjugation were observed.

\section{Latin diagnosis of Wickerhamomyces queroliae Rosa, Morais, Lachance et Pimenta sp. nov.}

In medio liquido glucosum et extractum levidinis post dies tres cellulae singulae aut binae; cellulae ovoidae aut ellipsoideae $(2-3 \times 2-4 \mu \mathrm{m})$. Post unum mensem sedimentum formantur. Cultura in agaro malti post dies $2\left(25{ }^{\circ} \mathrm{C}\right)$ parva, convexa, glabra et candida. In agaro farinae Zea mays post dies 14 mycelium ner pseudomycelium non-formantur. Species homothallica. Asci inconjugati et stabiles, et habentes 2-4 ascosporae petasiformes. Glucosum, maltosum et sucrosum fermentantur. Glucosum, maltosum, sucrosum, trehalosum, D-xylosum, L-arabinosum, D-ribosum, L-rhamnosum, ethanolum (lente), glycerolum, erythritolum, ribitolum, mannitolum, glucitolum, salicinum, acidum lacticum (variabile), acidum succinicum, acidum citricum (exigue et lente), xylitolum et acidum gluconicum assimilantur, at non-galactosum, L-sorbosum, raffinosum, inulinum, melibiosum, lactosum, melezitosum, cellobiosum, amylum solubile, D-arabinosum, methanolum, 2-propanolum, galactitolum, myo-inositolum, 2-ketogluconatum, glucosaminum, N-acetylglucosaminum, acetonum, ethyl acetas ner hexadecanum. Ethylaminum, lysinum, cadaverinum, natrium nitricum et natrium nitrosum assimilantur. Ad crescentiuam vitamina externa necessaria sunt. Augmentum in $37^{\circ} \mathrm{C}$. Habitat congregationem Anastrepha mucronata in Brazil. Typus UFMG-05-T200.1 ${ }^{\mathrm{T}}$. In collectione zymotica Centraalbureau voor Schimmelcultures, Trajectum ad Rhenum, sub no. CBS $10936^{\mathrm{T}}$ typus stirps deposita est.

\section{Description of Wickerhamomyces queroliae Rosa, Morais, Lachance \& Pimenta sp. nov.}

Wickerhamomyces queroliae (que.ro'li.ae. N.L. gen. fem. sing. n. queroliae of Querol, referring to Amparo Querol, in recognition of her contributions to yeast systematics and fermentation).

In glucose $(2 \%)$, yeast extract $(0.5 \%)$ broth after 3 days at $25^{\circ} \mathrm{C}$, cells are ovoid to ellipsoidal $(2-3 \times 2-4 \mu \mathrm{m})$. Budding is multilateral. Sediment is formed after 1 month, but no pellicle is observed. On YM agar after 2 days at $25{ }^{\circ} \mathrm{C}$, colonies are white, convex, smooth and opalescent. In Dalmau plates after 2 weeks on cornmeal agar, pseudomycelia or true mycelia are not formed. Homothallic. After 5 days on diluted $(1: 19)$ V8 agar, cells give rise to asci containing two to four hat-shaped ascospores (Fig. 3). Asci are unconjugated and ascospores are not liberated. Glucose, maltose and sucrose are fermented. Assimilation of carbon compounds: glucose, maltose, sucrose, trehalose, D-xylose, L-arabinose, D-ribose, L-rhamnose, ethanol (slow), glycerol, erythritol, ribitol, Dmannitol, D-glucitol, salicin, lactic acid (variable), succinic acid, citric acid (weak and slow), xylitol and gluconic acid. No growth occurs on galactose, L-sorbose, raffinose, inulin, melibiose, lactose, melezitose, cellobiose, soluble starch, Darabinose, methanol, 2-propanol, galactitol, myo-inositol, 2-ketogluconate, glucosamine, $\mathrm{N}$-acetylglucosamine, acetone, ethyl acetate or hexadecane. Assimilation of nitrogen compounds: positive for lysine, ethylamine- $\mathrm{HCl}$, cadaverine, nitrate and nitrite. Growth in vitamin-free medium is

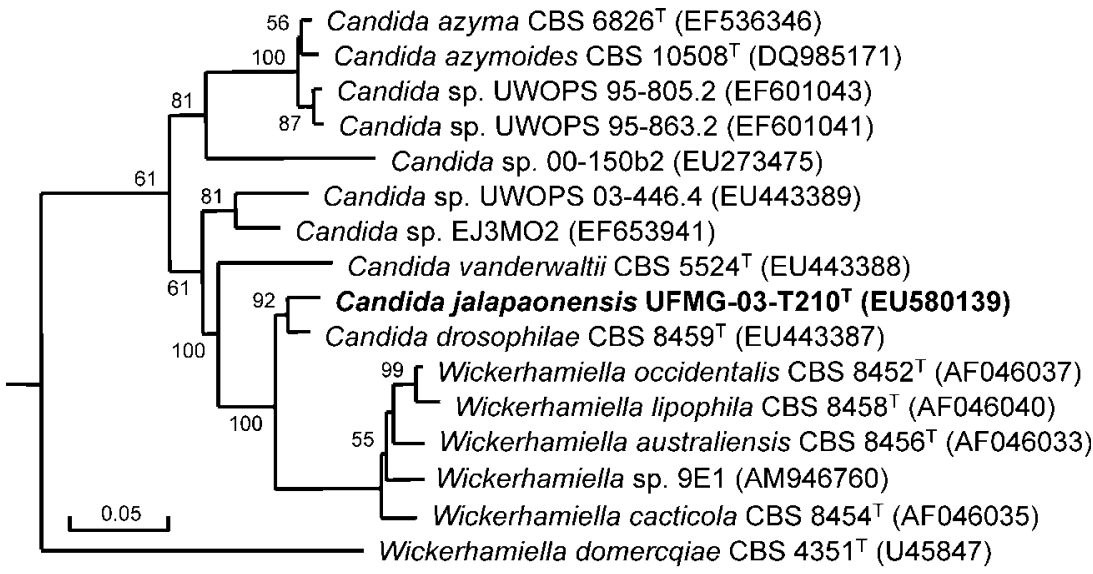

Fig. 2. Neighbour-joining tree based on largesubunit rRNA genes showing the placement of Candida jalapaonensis among related species in the Wickerhamiella clade. Bootstrap values greater than $50 \%$ are shown. Bar, 5 substitutions per 100 nucleotides. 

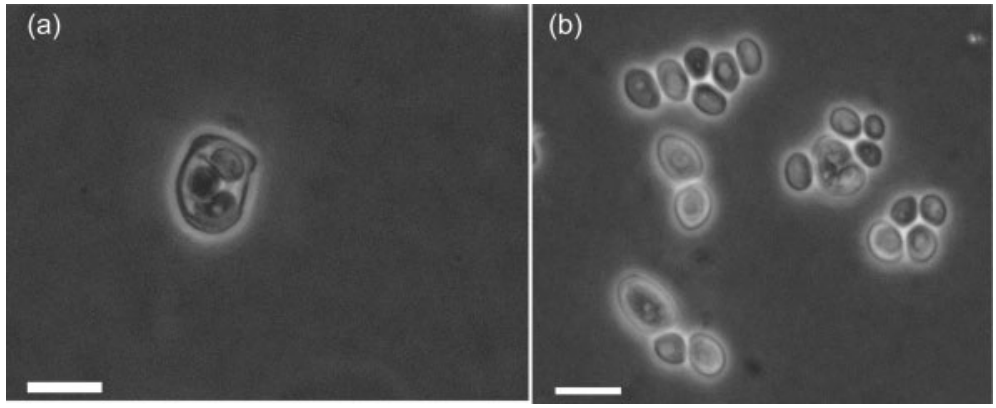

Fig. 3. Phase-contrast micrographs of cells of Wickerhamomyces queroliae UFMG-05T200.1 $1^{\top}$ on dilute $(1: 19)$ V8 agar after 5 days at $22{ }^{\circ} \mathrm{C}$. (a) Ascus with hat-shaped ascospores; (b) budding cells and an ascus with hat-shaped ascospores. Bars, $5 \mu \mathrm{m}$.

negative. Growth in amino acid-free medium is positive. Growth at $37{ }^{\circ} \mathrm{C}$ is positive. Growth on YM agar with $10 \%$ sodium chloride is negative. Growth in $50 \%$ glucose/yeast extract $(0.5 \%)$ is negative. Starch-like compounds are not produced. In $100 \mu \mathrm{g}$ cycloheximide $\mathrm{ml}^{-1}$ growth is variable. Urease activity is negative. Diazonium Blue B reaction is negative.

Habitat is larvae of Anastrepha mucronata (Diptera: Tephritidae) collected from fruit of Peritassa campestris ('Bacupari', Hippocrateaceae) in Ipuca ecosystem, in the state of Tocantins, Brazil. The type strain is UFMG-05$\mathrm{T} 200.1^{\mathrm{T}}$, isolated from larvae of $A$. mucronata collected from ripe fruit of $P$. campestris, Brazil. It has been deposited in the collection of the Yeast Division of the Centraalbureau voor Schimmelcultures, Utrecht, The Netherlands, as strain CBS $10936^{\mathrm{T}}\left(=\mathrm{NRRL} Y-48478^{\mathrm{T}}\right)$.

\section{Latin diagnosis of Candida jalapaonensis Rosa, Morais, Lachance et Pimenta sp. nov.}

In medio liquido glucosum et extractum levidinis post dies tres cellulae singulae aut binae; cellulae ovoidae aut ellipsoideae $(2-3 \times 2-4 \mu \mathrm{m})$. Post unum mensem pellicula et sedimentum formantur. Cultura in agaro malti post dies 2 $\left(25{ }^{\circ} \mathrm{C}\right)$ parva, convexa, glabra et candida. In agaro farinae Zea mays post dies 14 mycelium nec pseudomycelium nonformantur. Ascosporae non-formantur. Fermentatio nulla. Glucosum, galactosum, L-sorbosum, ethanolum (exigue), glycerolum, mannitolum, glucitolum, acidum succinicum, acetonum et hexadecanum assimilantur, at non-sucrosum, maltosum, trehalosum, raffinosum, inulinum, melibiosum, lactosum, melezitosum, cellobiosum, amylum solubile, Dxylosum, L-arabinosum, D-arabinosum, D-ribosum, L-rhamnosum, methanolum, 2-propanolum, erythritolum, ribitolum, galactitolum, myo-inositolum, 2-ketogluconatum, salicinum, acidum lacticum, acidum citricum, xylitolum, glucosaminum, $\mathrm{N}$-acetylglucosaminum, acidum gluconicum ner ethyl acetas. Ethylaminum, lysinum et cadaverinum assimilantur at non-natrium nitricum et natrium nitrosum. Ad crescentiuam vitamina externa necessaria sunt. Augmentum in $37{ }^{\circ} \mathrm{C}$ (variabile). Habitat floris in Brazil. Typus UFMG-03-T210 . In collectione zymotica Centraalbureau voor Schimmelcultures, Trajectum ad Rhenum, sub no. CBS $10935^{\mathrm{T}}$ typus stirps deposita est.

\section{Description of Candida jalapaonensis Rosa, Morais, Lachance \& Pimenta sp. nov.}

Candida jalapaonensis (ja.la.pa.o.nen'sis. N.L. nom. masc. sing. adj. jalapaonensis referring to the place where this yeast was found).

In glucose $(2 \%)$, yeast extract $(0.5 \%)$ broth after 3 days at $25{ }^{\circ} \mathrm{C}$, cells are ovoid to ellipsoidal $(2-3 \times 2-4 \mu \mathrm{m})$. Budding is multilateral (Fig. 4). Sediment and pellicle are formed after 1 month. On YM agar after 2 days at $25^{\circ} \mathrm{C}$, colonies are white, convex, smooth and opalescent. In Dalmau plates after 2 weeks on cornmeal agar, pseudomycelia or true mycelia are not formed. Ascospores are not formed. Fermentation of glucose is negative. Assimilation of carbon compounds: glucose, galactose, L-sorbose, ethanol (weak), glycerol, D-mannitol, D-glucitol, succinic acid, acetone and hexadecane are assimilated. No growth occurs on sucrose, maltose, trehalose, raffinose, inulin, melibiose, lactose, melezitose, cellobiose, soluble starch, Dxylose, L-arabinose, D-arabinose, D-ribose, L-rhamnose, methanol, 2-propanol, erythritol, ribitol, galactitol, myoinositol, 2-ketogluconate, salicin, lactic acid, citric acid, xylitol, glucosamine, $\mathrm{N}$-acetylglucosamine, gluconic acid or ethyl acetate. Assimilation of nitrogen compounds: positive for lysine, ethylamine- $\mathrm{HCl}$, cadaverine, and negative for nitrate and nitrite. Growth in vitamin-free medium is

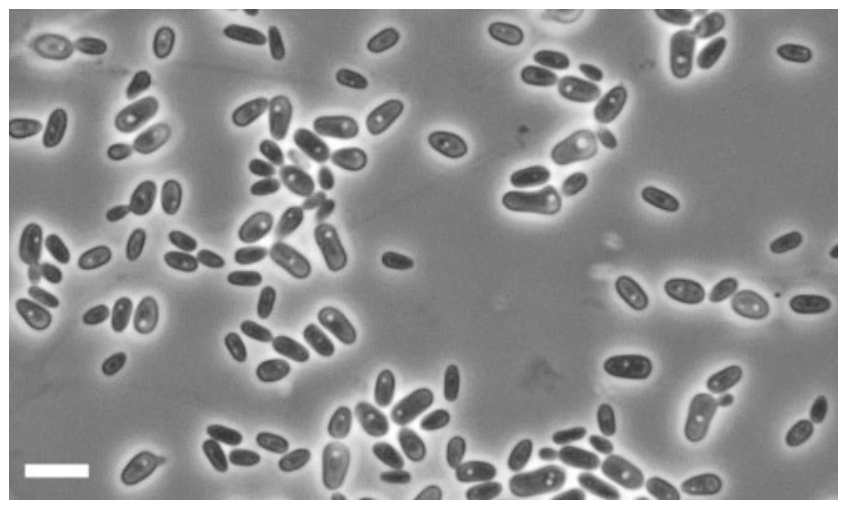

Fig. 4. Phase-contrast micrograph of Candida jalapaonensis UFMG-03-T210 ${ }^{\top}$ on yeast extract-malt extract agar after 5 days at $22{ }^{\circ} \mathrm{C}$. Bar, $5 \mu \mathrm{m}$. 
negative. Growth in amino acid-free medium is positive. Growth at $37{ }^{\circ} \mathrm{C}$ is variable. Growth on YM agar with $10 \%$ sodium chloride is negative. Growth in $50 \%$ glucose/yeast extract $(0.5 \%)$ is negative. Starch-like compounds are not produced. In $100 \mu \mathrm{g}$ cycloheximide $\mathrm{ml}^{-1}$ growth is negative. Urease activity is negative. Diazonium Blue B reaction is negative.

Habitat is flowers of Centropogon cornutus (Campanulaceae) in the Cerrado ecosystem, in the state of Tocantins, Brazil. The type strain is UFMG-03-T2 $10^{\mathrm{T}}$, isolated from flowers of Centropogon cornutus in Brazil. It has been deposited in the collection of the Yeast Division of the Centraalbureau voor Schimmelcultures, Utrecht, The Netherlands, as strain CBS $10935^{\mathrm{T}}\left(=\right.$ NRRL Y $\left.-48477^{\mathrm{T}}\right)$.

\section{Acknowledgements}

This work was funded by Conselho Nacional de Desenvolvimento Cientifico e Tecnológico (CNPq, process no. 477528/03-1), Fundação do Amparo a Pesquisa do Estado de Minas Gerais (FAPEMIG, process numbers no. CBB - 378/04 and CBB APQ- 3484-4.01/07), and the Natural Science and Engineering Research Council of Canada (M.-A. L.).

\section{References}

Cruz-López, L., Malo, E. A., Toledo, J., Virgen, A., Del Mazo, A. \& Rojas, J. C. (2006). A new potential attractant for Anastrepha obliqua from Spondias mombin fruits. J Chem Ecol 32, 351-365.

Kurtzman, C. P. \& Fell, J. W. (editors) (1998). The Yeasts, a Taxonomic Study. Amsterdam: Elsevier.

Kurtzman, C. P., Robnett, C. J. \& Basehoar-Powers, E. (2008). Phylogenetic relationships among species of Pichia, Issatchenkia and Williopsis determined from multigene sequence analysis, and the proposal of Barnettozyma gen. nov., Lindnera gen. nov. and Wickerhamomyces gen. nov. FEMS Yeast Res 8, 939-954.

Lachance, M.-A., Rosa, C. A., Starmer, W. T., Schlag-Edler, B., Barker, J. S. \& Bowles, J. M. (1998). Wickerhamiella australiensis, Wickerhamiella cacticola, Wickerhamiella occidentalis, Candida drosophilae and Candida lipophila, five new related yeast species from flowers and associated insects. Int J Syst Bacteriol 48, 1431-1443.

Lachance, M. A., Bowles, J. M., Starmer, W. T. \& Barker, J. S. F. (1999). Kodamaea kakaduensis and Candida tolerans, two new ascomycetous yeast species from Australian Hibiscus flowers. Can J Microbiol 45, 172-177.

Lachance, M. A., Bowles, J. M., Mueller, C. \& Starmer, W. T. (2000). On the biogeography of yeasts in the Wickerhamiella clade and description of Wickerhamiella lipophila sp. nov., the teleomorph of Candida lipophila. Can J Microbiol 46, 1145-1148.

Morais, P. B., Teixeira, L. C. S. R., Bowles, J. M., Lachance, M. A. \& Rosa, C. A. (2004). Ogataea falcaomoraisii sp. nov., a sporogenous methylotrophic yeast from tree exudates. FEMS Yeast Res 5, 81-85.

Myers, N., Mittermeier, R. A., Mittermeir, C. G., da Fonseca, G. A. B. \& Kent, J. (2000). Biodiversity hotspots for conservation priorities. Nature 403, 853-858.

Rosa, C. A., Morais, P. B., Lachance, M. A., Pimenta, R. S., Santos, R. O., Trindade, R. C., Figueroa, D. L., Resende, M. A. \& Bragança, M. A. L. (2006). Candida azymoides sp. n. (Ascomycota), a yeast species from tropical fruits and larva of Anastrepha mucronata (Diptera: Tephritidae). Lundiana 7, 83-86.

Rosa, C. A., Lachance, M.-A., Teixeira, L. C. R. S., Pimenta, R. P. \& Morais, P. B. (2007). Metschnikowia cerradonensis sp. nov., a yeast species isolated from ephemeral flowers and their nitidulid beetles in Brazil. Int J Syst Evol Microbiol 57, 161-165.

Rosa, C. A., Jindamorakot, S., Limtong, S., Nakase, T., Lachance, M.-A., Fidalgo-Jiménez, A., Daniel, H.-M., Pagnocca, F. C., Inácio, J. \& Morais, P. B. (2009). Synonymy of the yeast genera Moniliella and Trichosporonoides and proposal of Moniliella fonsecae sp. nov. and five new species combinations. Int J Syst Evol Microbiol 59, 425-429.

Thompson, J. D., Higgins, D. G. \& Gibson, T. J. (1994). CLUSTAL W: improving the sensitivity of progressive multiple sequence alignment through sequence weighting, position-specific gap penalties and weight matrix choice. Nucleic Acids Res 22, 4673-4680.

Wickerham, L. J. \& Burton, K. A. (1954). A simple technique for obtaining mating types in heterothallic diploid yeasts, with special reference to their uses in the genus Hansenula. J Bacteriol 67, 303308.

Yarrow, D. (1998). Methods for the isolation and identification of yeasts. In The Yeasts, a Taxonomic Study, 4th edn, pp. 77-100. Edited by C. P. Kurtzman \& J. W. Fell. Amsterdam: Elsevier. 